Crop Breeding and Applied Biotechnology 14: 49-53 2014

Brazilian Society of Plant Breeding. Printed in Brazil

\title{
ARTICLE
}

\section{Yield performance of half-sib families of physic nut (Jatropha curcas L.)}

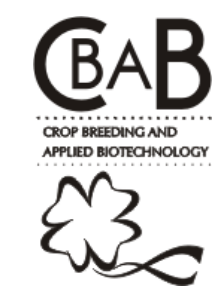

\author{
Victor Mousinho Spinelli ${ }^{1}$, Luiz Antônio dos Santos Dias ${ }^{1 *}$, Rodrigo Barros Rocha² and Marcos Deon Vilela Resende ${ }^{3}$
}

Received 25 August 2013

Accepted 09 February 2014

\begin{abstract}
Among the oilseed plants, physic nut stands out for its yield potential and for the quality of its oil for biodiesel and biokerosene production. Currently, low seed yield, uneven fruit maturation and the lack of high yielding genotypes limit the viability of this crop. Here we evaluated the yield performance of a population, structured in 16 half-sib families, in the 2nd, 3rd and 4th years after planting (2009-11). Seed yield showed variability. The families maintained their relative performance over time. Contrary to expectations, seed yield was lower in the 4th year, probably due the increased competition between plants and leafhopper (Empoasca spp) incidence. Temporal yield stability and adaptability estimates indicated a trend toward maintaining plant superiority over time, and families 7 (1059 $\left.\mathrm{kg} \mathrm{ha}^{-1}\right)$ and $12\left(984 \mathrm{~kg} \mathrm{ha}^{-1}\right)$ showed the best stability and yield performance. Physic nut has the potential for greater yield gains.
\end{abstract}

Key words: Jatropha curcas L., temporal stability and adaptability, biodiesel production.

\section{INTRODUCTION}

Among oilseed plants, physic nut (Jatropha curcas L.) stands out for its yield potential, superior to traditional oilseeds, and for the physiochemical characteristics of its oil, which lends itself to biodiesel and biokerosene production (Dias 2011). This oilseed also stands out as a perennial crop alternative, without the need for annual replanting, and as a non-food crop, and therefore it does not directly compete against food crops. In spite of these potential advantages, it is important to consider that this species is still passing through the domestication process (Juhász et al. 2010, Freitas et al. 2011, Dias et al. 2012). Low yield, uneven fruit maturation and lack of improved cultivars with greater yield limit the viability of this crop (Dias et al. 2007). From the initial seed yield expectation of $4 \mathrm{tha}^{-1} \mathrm{year}^{-1}$ or more, yields of less than $2 \mathrm{t} \mathrm{ha}^{-1}$ are being observed. According to Spinelli et al. (2010) the decomposition of the yield components of this oilseed crop showed that more than $90 \%$ of the oil yield depends on the seed yield.

However, studies have confirmed an express range of variation in yield for this oilseed, from 0.2 to $2 \mathrm{~kg} \mathrm{plant}^{-1}$ (Francis et al. 2005, Jongschaap et al. 2007). Drumond et al. (2010) described accessions responsive to environmental improvements that produced, at 12 months from planting,
$2.12 \mathrm{~kg} \mathrm{plant}^{-1}$ of seed in an irrigated system. On the other hand, in cerrado (tropical savanna) and without irrigation, Laviola et al. (2011) observed variation in seed yield from 0 to $0.18 \mathrm{~kg} / \mathrm{plant}^{-1}$ in the first year of assessment of 110 accessions. Variability for resistance to broad mite (Evaristo et al. 2013), to powdery mildew and absence of toxicity in seeds and to proportion of male and female flowers (Juhász et al. 2009, Laviola et al. 2011) have also been reported and characterized in the field.

In this scenario, the aim of this study was to evaluate seed yield and its stability in a population structured in half-sib families assessed in the $2 \mathrm{nd}, 3 \mathrm{rd}$ and 4 th years after planting. For the first time, we report the seed yield of mature plant.

\section{MATERIAL AND METHODS}

\section{Field trial}

The trial was set up in February 2008 in the experimental field of the Agriculture and Forest Research Center of the Brazilian Agricultural Research Corporation (Embrapa), Porto Velho, RO, Brazil. The trial is represented by half-sib families of $J$. curcas, derived from a population composed of wild seed of unknown genetic origin from visually selected plants in the municipality of Ariquemes, RO.

\footnotetext{
${ }^{1}$ Universidade Federal de Viçosa (UFV), Departamento de Fitotecnia, 36.570-900, Viçosa, MG, Brazil. *E-mail: lasdias@ufv.br

${ }^{2}$ Embrapa Rondônia, CP 172, 76.815-800, Porto Velho, RO, Brazil

${ }^{3}$ Embrapa Floresta. Current address: UFV, Departamento de Engenharia Florestal, 36.570-900, Viçosa, MG, Brazil
} 
Sixteen half-sib families were assessed in the $2 \mathrm{nd}$, 3rd and 4th years after planting, set up in randomized blocks with three replications, eight-plant linear plots and a spacing of $3.0 \times 2.0 \mathrm{~m}$. Final planting was made with 30-day old seedlings grown in a nursery in February 2008. At planting, $200 \mathrm{~g}$ of triple superphosphate, $50 \mathrm{~g}$ of FTE and 50 $\mathrm{g}$ of potassium chloride $(\mathrm{KCl})$ were used, in $20 \times 20 \times 20$ $\mathrm{cm}$ hills. Four tons of lime was distributed per hectare on the soil surface, at first year of planting, after soil analysis (Table 1). As of the second year, fertilization was carried out with the application of $50 \mathrm{~g}$ de urea, $60 \mathrm{~g}$ of triple superphosphate and $40 \mathrm{~g}$ of $\mathrm{KCl}$ in topdressing, three months before the main harvests of the crop in the region, which occur in January and June (Dias et al. 2007, Laviola and Dias 2008). Weed control was carried out manually and chemically (herbicide). From the time of setting up the trial, no agricultural chemicals were used for pest and disease control of the crop.

Climate in the region of the trial is tropical type Aw, hot and wet, with a well-defined dry period from June to September, annual mean temperature of $25^{\circ} \mathrm{C}$, mean annual rainfall of 2,354 $\mathrm{mm}$ and mean annual evapotranspiration of $851 \mathrm{~mm}$. The soil of the experimental area (see Table 1) is classified as an oxisol (Embrapa 1999), with a very clayey texture, being improved through fertilization.

\section{Seed yield assessment}

Uneven maturation of the fruits is a characteristic of this oilseed plant. In the region, the plant bears fruit throughout the entire rainy period, which extends from November to June. Seed yield was assessed in three crop years (2009, 2010 and 2011), including 5 harvests (Dec/2009, Jun/2009, Jan/2010, Jun/2010 and Dec/2011). The June 2011 harvest was not made due to the severe attack of leafhopper ( $\mathrm{Em}$ poasca spp.) in the flowering and seed-filling period, from March to May 2011, which compromised yield.

The fruits in the final stage of maturity were gathered from the trees and from the projections of their canopies, dried in the shade for around seven days, and then processed. After processing, seed moisture was measured. Seed lots with moisture content of less than $9 \%$ had their weight assessed.

\section{Statistical analyses}

Analyses of variance, mean tests, and display analysis were processed with the data obtained in the three crop years. The seed yield data were subjected to analysis of variance in a split-plot model, with blocks and families being allocated in the plot and years of production in the subplot, both effects considered as fixed, according to the model (Dias and Barros 2009):

$$
Y_{i j}=u+f_{i}+b_{j}+(f b)_{j}+a_{k}+(f a)_{\mathrm{k}}+\varepsilon_{i j k}
$$

$Y_{i j}=$ the value observed in the plot of the $\mathrm{i}$-th family, in the $\mathrm{j}$-th block and $\mathrm{k}$-th year; $u=$ the overall mean; $f_{i}=$ the effect of the i-th family; $b_{j}=$ the effect of the j-th block; $(f b)_{j}$ $=$ the experimental error at the plot level; $a_{k}=$ the effect of years; $(f a)_{\mathrm{k}}=$ the interaction effect between families and years; $\varepsilon_{i j k}=$ the experimental error at the subplot level. The mean values of seed yield of 16-families were grouped by the Scott and Knott (1974) test at 5\% probability.

\section{Analysis of temporal adaptability and phenotypic stability}

Analysis of adaptability was processed with the mean values of seed yield from three replications, considering each production year as an environment. The stability and adaptability statistic adopted was $\mathrm{P}_{\mathrm{i}}$ from Lin and Binns (1988), as defined bellow:

$$
P_{i}=\frac{\sum_{j=1}^{n}\left(Y_{j}-M_{j}\right)^{2}}{2 n}
$$

where $P_{i}$ is the estimate of stability and of adaptability of the $\mathrm{i}$-th family; $Y_{i j}$ is the yield of $\mathrm{i}$-th family in the $\mathrm{j}$-th crop year; $M_{j}$ is the maximum response observed among all the families in the $\mathrm{j}$-th crop year; $\mathrm{n}$ : number of years in production. Lin and Binns (1988) use only one stability parameter, $\mathrm{P}_{\mathrm{i}}$. Nonparametric estimates, such as $\mathrm{P}_{\mathrm{i}}$, stand out by their ease of interpretation and for being based on few presuppositions of analysis.

\section{RESULTS AND DISCUSSION}

Analyses of variance indicate that the effects of families

Table 1. Soil chemical attributes in the 0-20 cm layer, evaluated in 2009, 2010 and 2011 in the experimental area with physic nut (Jatropha curcas L.),

\begin{tabular}{|c|c|c|c|c|c|c|c|c|c|}
\hline \multirow{2}{*}{ Date } & \multirow{2}{*}{$\mathbf{p H}$} & $\mathbf{P}$ & $\mathbf{K}$ & $\mathbf{C a}$ & Mg & $\mathbf{A l}+\mathbf{H}$ & Al & \multirow{2}{*}{$\begin{array}{l}\text { O.M. } \\
\left(\mathrm{g} \mathrm{kg}^{-1}\right)\end{array}$} & \multirow{2}{*}{$\begin{array}{l}\mathbf{V} \\
(\%)\end{array}$} \\
\hline & & $\left(\mathrm{mg} \mathrm{dm} \mathrm{m}^{-3}\right)$ & \multicolumn{5}{|c|}{ - } & & \\
\hline $09 / 2009$ & 4.4 & 3.0 & 2.54 & 13.1 & 9.7 & 174.9 & 33.6 & 23.1 & 13 \\
\hline $09 / 2011$ & 5.0 & 2.0 & 1.23 & 45.1 & 21.5 & 90.8 & 6.8 & 27.4 & 43 \\
\hline
\end{tabular}
located in the municipality of Porto Velho, RO, Brazil

P: phosphorus (Mehlich), K: exchangeable potassium (Mehlich), Ca: exchangeable calcium, Mg: exchangeable magnesium, Al+H: titratable acidity, Al: exchangeable aluminum, O.M.: organic matter and V: base saturation. 
and of crop years were significant, at $5 \%$ and $1 \%$ probability, respectively, for seed yield. In contrast, the effect of the family $x$ year interaction was not significant, indicating that the families maintained their relative performance over time, and that the factors assessed (families and years) may be interpreted separately. Even in a single environment, a great yield variation is observed, as the results of the present study reveal.

Widely used for inference regarding experimental precision, the coefficient of variation $(\mathrm{CV})$ was of a lower magnitude $\left(\mathrm{CV}_{\mathrm{a}}=22.56 \%\right.$ and $\left.\mathrm{CV}_{\mathrm{b}}=10.87 \%\right)$ than that observed in other studies. Values from $25 \%$ to $35 \%$ were considered adequate by different authors (Jongschaap et al. 2007, Juhász et al. 2010, Laviola et al. 2011) in assessment of experiments with this oilseed plant under different edaphic and climatic conditions. In addition to good experimental practice, the lower CV in this study is owing to the assessment of mean values of families in the interpretation of the yield performance.

Agronomic assessments have shown the variability of the yield components of this oilseed crop (Jongschaap et al. 2007, Mishra 2009, Brittaine and Lutaladio 2010). The existence of genetic variability is a basic condition for achieving gains from selection. According to Resende (2002), interpretation of measurements over time is fundamental for characterization of the yield performance of perennial plant species that have a long reproductive cycle and differentiated expression of traits over time, as J. curcas.

According to Dias et al. (2007) and Brittaine and Lutaladio (2010), J. curcas requires from three to four years to reach productive age, while few studies have quantified production of trees over three years from planting. In this study, the interpretation of the means of yield of the families in the 2nd, 3rd and 4th years after planting show reduced seed production in the 4th crop year and a tendency for the more productive families in maintaining their superiority over time (Table 2). For comparison of the yield performance of the families, the Scott and Knott (1974) test was used at 5\% probability, which allows classification of their performance in mutually exclusive groups (Table 2). The mean values of the families were differentiated in the three years and the yield decreased significantly in the 4th year, being equal to the yield of the 2 nd year. Families 7 and 12 showed the best mean performance (Table 2).

Seed yield is a trait of complex genetic control, and its expression is affected by the action of thousands of genes and by the environment. Unconfirmed yield expectations of this oilseed crop based on observations of isolated plants, without considering the reduction in plant growth that occurs in higher density planting, make characterization of the yield potential of this crop a relevant object of research. In the present study, seed yield in the 4th year was less than in the 3rd year. The severe attack from leafhopper (Empoasca spp.) and and the increased competition between plants due to it larger size certainly limited yield in the 4th year. The leafhopper is the main pest in J. curcas in the Amazon region, with incidence from March to June. Yellowing and shriveling of leaves caused by the incidence of leafhoppers resulted in reduction of plant photosynthetic activity, with flower and fruit abortion. Harvest in June 2011 was completely compromised by the attack of this pest, reducing yield in the 4th year.

The restriction in vegetative growth observed in plants that developed their canopies in less space, as of the second year, was also considered to be an important yield limiting factor. Assessments of yield components of this oilseed indicate that seed yield is principally affected by canopy development of the plants (Spinelli et al. 2010). In general, greater spacings result in greater canopy diameters due to greater incidence of light, which stimulated lateral growth of the plants.

In addition to improving crop conditions, the increase in seed yield of this oilseed depends on identification of genetically superior plants, with greater fruit production

Table 2. Means of seed yield $\left(\mathrm{kg} \mathrm{ha}^{-1}\right)$ of 16 half-sib families of physic nut (Jatropha curcas L.) evaluated during three crop years

\begin{tabular}{|c|c|c|c|}
\hline & & $\begin{array}{l}\text { Years after } \\
\text { planting }\end{array}$ & \\
\hline Families & $2^{\text {nd }}$ & $3^{\text {rd }}$ & $4^{\text {th }}$ \\
\hline 1 & $388.40 \mathrm{~b}$ & $763.00 \mathrm{c}$ & $424.03 \mathrm{~b}$ \\
\hline 2 & $476.60 \mathrm{a}$ & $890.20 \mathrm{~b}$ & $495.97 \mathrm{a}$ \\
\hline 3 & $473.13 \mathrm{a}$ & $813.06 \mathrm{c}$ & $527.60 \mathrm{a}$ \\
\hline 4 & $411.87 \mathrm{~b}$ & $760.87 \mathrm{c}$ & $486.03 \mathrm{a}$ \\
\hline 5 & $423.20 \mathrm{~b}$ & $817.93 \mathrm{c}$ & $533.30 \mathrm{a}$ \\
\hline 6 & $499.70 \mathrm{a}$ & $834.30 \mathrm{c}$ & $460.40 \mathrm{~b}$ \\
\hline 7 & 517.13 a & 1059.67 a & 563.93 a \\
\hline 8 & $488.90 \mathrm{a}$ & $837.13 \mathrm{c}$ & $494.60 \mathrm{a}$ \\
\hline 9 & $335.03 \mathrm{~b}$ & $629.57 \mathrm{~d}$ & $372.57 \mathrm{~b}$ \\
\hline 10 & $479.03 \mathrm{a}$ & $901.07 \mathrm{~b}$ & $588.70 \mathrm{a}$ \\
\hline 11 & $473.23 \mathrm{a}$ & $840.83 \mathrm{c}$ & $467.67 \mathrm{~b}$ \\
\hline 12 & $477.20 \mathrm{a}$ & 984.20 a & 563.80 a \\
\hline 13 & $405.27 \mathrm{~b}$ & $741.23 \mathrm{c}$ & $359.10 \mathrm{~b}$ \\
\hline 14 & $528.33 \mathrm{a}$ & $925.00 \mathrm{~b}$ & $575.87 \mathrm{a}$ \\
\hline 15 & $422.63 \mathrm{~b}$ & $829.67 \mathrm{c}$ & $499.40 \mathrm{a}$ \\
\hline 16 & $414.03 \mathrm{~b}$ & $660.80 \mathrm{~d}$ & $415.50 \mathrm{~b}$ \\
\hline Mean & 450.85 & 830.53 & 489.27 \\
\hline
\end{tabular}

Means followed by the same letters in the column constitute a statistically homogeneous group of families within year crop, by the Scott and Knott (1974) test at $5 \%$ probability. 
VM Spinelli et al.

Table 3. Estimates of temporal adaptability and stability $\mathrm{P}_{\mathrm{i}}$ parameter for seed yield $\left(\mathrm{kg} \mathrm{ha}^{-1}\right)$ in 16 half-sib families of physic nut (Jatropha curcas L.), on the average of three crop years

\begin{tabular}{llll}
\hline Family & Mean & $\mathrm{P}_{\mathrm{i}}$ & Order \\
\hline 7 & 713.6 & 123.1 & 1 \\
12 & 675.1 & 1488.3 & 2 \\
14 & 676.4 & 3050.0 & 3 \\
10 & 656.3 & 4597.4 & 4 \\
2 & 620.9 & 6665.8 & 5 \\
8 & 606.9 & 9988.5 & 6 \\
11 & 593.9 & 10928.9 & 7 \\
3 & 604.6 & 11265.3 & 8 \\
6 & 598.1 & 11345.2 & 9 \\
15 & 583.9 & 12007.8 & 10 \\
5 & 591.5 & 12092.9 & 11 \\
4 & 552.9 & 18897.7 & 12 \\
1 & 525.1 & 22451.3 & 13 \\
13 & 501.9 & 28210.2 & 14 \\
16 & 496.8 & 33692.9 & 15 \\
9 & 445.7 & 44844.1 & 16 \\
\hline
\end{tabular}

efficiency. For the purpose of checking for higher yielding families with greater temporal yield stability, the nonparametric measurement $\mathrm{P}_{\mathrm{i}}$ of Linn and Binns (1988) was used. Upon stratifying the measurements, the method allows ordering of the best families in the most and least favorable years in regard to seed production. The order of number 1 was attributed to the family with the lowest estimate of the respective parameter, advancing up to the order of number f, attributed to the family with the greatest value of this estimate. In general, consistency was seen in the ordering of the families, and families 7 and 12 exhibited the best performance and adaptability in all harvest years (Table 3 ).

Based on the yield performance quantified in this study, we believe that $J$. curcas has the potential for achieving higher yields through plant selection and/or adaptation of management practices. Abdelgadir et al. (2010), Ghosh et al. (2010), Pan and Xu (2011) and Gouveia et al. (2012) reported promising results through the use of growth regulators, with increasing in seed yield of this crop. Silva et al. (2012) found that tip pruning increased seed yield per plant and concentrated the production cycle of the plant.

\section{CONCLUSIONS}

1- The $\mathrm{F}$ test revealed the existence of variability for seed yield among half-sib families of $J$. curcas, showing the possibility for achieving gain from selection.

2- The effect of the family $\mathrm{x}$ year interaction was non-significant, indicating that families maintained their performance over time. Families 7 and 12 stood out as the highest yielding and the most stable over time.

3- The severe incidence of leafhopper and increased competition between plants limited yield in the fourth year after planting.

4- $J$. curcas shows potential for greater yield gains.

\section{ACKNOWLEDGEMENTS}

The authors thank CAPES, CNPq and FAPEMIG for financial support.

\section{Desempenho produtivo de famílias de meios-irmãos de pinhão-manso (Jatropha curcas L.)}

Resumo - Dentre as oleaginosas alternativas destaca-se pinhão-manso pelo seu potencial de rendimento de grãos e pela qualidade de seu óleo para biodiesel e bioquerosene. Atualmente, a baixa produção de grãos, a desuniformidade na maturação de frutos e a inexistência de genótipos de alto rendimento limitam a competitividade desse cultivo. Avaliamos o desempenho de uma população estruturada em famílias de meios-irmãos, no $2^{0}, 3^{0}$ e $4^{0}$ anos pós-plantio (2009-2011). A produção de grãos mostrou variabilidade. As famílias mantiveram seu desempenho relativo ao longo do tempo. Contrariando as expectativas, a produtividade de grãos foi menor no $4^{0}$ ano, devido provavelmente à maior competição entre plantas e ao ataque de cigarrinhas (Empoasca spp). Estimativas de estabilidade e adaptabilidade temporal da produção indicaram tendência de manutenção da superioridade das plantas ao longo dos anos, destacando-se as famílias $7\left(1059 \mathrm{~kg} \mathrm{ha}^{-1}\right)$ e $12\left(984 \mathrm{~kg} \mathrm{ha}^{-1}\right)$ como as mais estáveis e produtivas. Pinhão manso apresenta potencial para maiores ganhos de produtividade.

Palavras-chave: Jatropha curcas L., adaptabilidade e estabilidade temporal, produção de biodiesel.

\section{REFERENCES}

Abdelgadir HA, Jager AK, Johnson SD and Van Staden J (2010) Influence of plant growth regulators on flowering, fruiting, seed oil content, and oil quality of Jatropha curcas. South African Journal of Botany 76: 440-446.
Brittaine R and Lutaladio N (2010) Jatropha: a smallholder bioenergy crop the potential for pro-poor development. Integrated Crop Management 8: 1-96.

Dias LAS (2011) Biofuel plant species and the contribution of genetic improvement. Crop Breeding and Applied Biotechnology 11(S1): 
$16-26$.

Dias LAS and Barros WS (2009) Biometria experimental. Suprema, Viçosa, 409p.

Dias LAS, Missio RF and Dias DCFS (2012) Antiquity, botany, origin and domestication of Jatropha curcas (Euphorbiaceae), a plant species with potential for biodiesel production. Genetics and Molecular Research 11: 2719-2728.

Dias LAS, Leme LP, Laviola BG, Pallini Filho A, Pereira OL, Carvalho M, Manfio CE, Santos AS, Souza LCA, Oliveira TS and Dias DCFS (2007) Cultivo de pinhão-manso (Jatropha curcas L.) para produção de óleo combustível. Suprema, Viçosa, 40p.

Drumond MA, Santos CAF, Oliveira VR, Martins JC, Anjos JB and Evangelista MRV (2010) Agronomic performance of different genotypes of physic nut in the semi-arid zone of Pernambuco state. Ciência Rural 40: 44-47.

Embrapa - Empresa Brasileira de Pesquisa Agropecuária (1999) Sistema brasileiro de classificação de solos. Embrapa, Rio de Janeiro.

Evaristo AB, Venzon M, Matos FS, Freitas RG, Naomi KK and Dias LAS (2013) Susceptibility and physiological responses of Jatropha curcas L. accessions to broad mite infestation. Experimental \& Applied Acarology 59: 1-8.

Francis GR, Edinge R and Becker K (2005) Concept for simultaneous wasteland reclamation, fuel production, and socio economic development in degraded areas in India: need, potential and perspectives of Jatropha plantations. Natural Resources Forum 29: 12-24.

Freitas RG, Missio RF, Matos FS, Resende MDV and Dias LAS (2011) Genetic evaluation of Jatropha curcas: an important oilseed for biodiesel production. Genetics and Molecular Research 10: 14901498.

Ghosh A, Chikara J, Chaudhary DR, Prakash AR, Boricha G and Zala A (2010) Paclobutrazol arrests vegetative growth and unveils unexpressed yield potential of Jatropha curcas. Journal of Plant Growth Regulation 29: 307-315.

Jongschaap REE, Corré WJ, Bindraban PS and Brandenburg WA (2007) Claims and facts on Jatropha curcas L. Plant Research International, Wageningen, (Report 158).

Juhász ACP, Morais DLB, Soares BO, Pimenta S, Rabello HO and
Resende MDV (2010) Parâmetros genéticos e ganho com a seleção em populações de pinhão-manso (Jatropha curcas). Pesquisa Florestal Brasileira 30: 25-35.

Juhász ACP, Pimenta S, Oliveira B, Morais DLB and Rabello HO (2009) Biologia floral e polinização artificial de pinhão-manso. Pesquisa Agropecuária Brasileira 44: 1073-1077.

Laviola BG and Dias LAS (2008) Teor e acúmulo de extração de nutrientes em folhas e frutos de pinhão manso. Revista Brasileira de Ciência do Solo 32: 1969-1975.

Laviola BG, Bhering LL, Mendonça S, Rosado TB and Albrecht JC (2011) Caracterização morfo-agronômica do banco de germoplasma de pinhão manso na fase jovem. Bioscience Journal 27: 371-379.

Gouveia EJ, Rocha RB, Laviola BG, Ramalho AR, Ferreira MGR and Dias LAS (2012) Aumento da produção de grãos de pinhão-manso pela aplicação de benziladenina. Pesquisa Agropecuária Brasileira 47: 1541-1545.

Lin CS and Binns MR (1988) A superiority measure of cultivar performance for cultivar x location data. Canadian Journal Plant Science 68: 193-198.

Mishra DK (2009) Selection of candidate plus phenotypes of Jatropha curcas L. using method of paired comparisons. Biomass and Bioenergy 33: 542-545.

Pan BZ and Xu ZF (2011) Benzyladenine treatment significantly increases the seed yield of the biofuel plant Jatropha curcas. Journal of Plant Growth Regulation 30: 166-174.

Resende MDV (2002) Genética biométrica e estatística no melhoramento de plantas perenes. Embrapa Informação Tecnológica, Brasília,

Scott AJ and Knott M (1974) A cluster analysis method for grouping means in the analysis of variance. Biometrics 30: 507-512.

Silva VA, Morais DLBM, Kakida J, Ferreira EA and Silva VF (2012) Concentração do ciclo de produção de pinhão-manso por meio de podas de formação ou de produção. Pesquisa Agropecuária Brasileira 47: 134-137.

Spinelli VM, Rocha RB, Ramalho AR, Marcolan AL, Vieira JR, Fernandes CF, Militão JSLT and Dias LAS (2010) Primary and secondary yield components of the oil in physic nut (Jatropha curcas L.). Ciência Rural 40: 1752-1758. 